\title{
A Panorama of England and the English Through Translations of English Romantic Poetry Into Serbo-Croatian
}

\author{
Jelena Otasevic \\ University Mediterranean, Podgorica, Montenegro
}

\begin{abstract}
The paper deals with the image of English, i.e., the way the English were represented, the country and the people, in translations of the poetry of major English Romantic poets into the Serbo-Croatian language, the official language of former Yugoslavia: Wordsworth, Coleridge, Byron and Shelley. The first translation of an English Romantic poem was published in 1831 at the time when Yugoslav peoples were split under foreign governments of Austro-Hungarian and Ottoman Empires and later, during the twentieth century, they were healing the wounds of the two world wars. The English were seen, or wanted to be seen as liberal, rebellious, ready to die for the just cause, through the verses of their major Romantic poets; in both centuries, some of them seemed apposite for translation while encouraging national liberation spirit and social justice, patriotism, and some were read in that key despite the original, thanks to translators' efforts to make it look that way. Translators were not solely guided by the assessment of the source culture readership and critics, but by the needs of the target culture too. As a result of such tendencies of adjusting Romantics to national purpose, Byron's satirical works remained completely neglected, Wordsworth was primarily seen as a poet of nature, and Coleridge's irrational visions were inappropriate for the 20th century dominant communist doctrine relying on rational, material rather than spiritual; Shelley's longer poems were not translated in its entirety, only its excerpts, explicitly emphasizing liberty and equality.
\end{abstract}

Keywords: English Romanticism, Serbo-Croatian, Wordsworth, Coleridge, Byron, Shelley

\section{Introduction}

The phrase "A Panorama of England and the English" in the title refers not only to the image of landscape and outer morphology of the English ground seen in the image of the translated English Romantic poetry by Serbo-Croatian readership, but to the cultural and literary depth and inner life of the nation as well, deeply rooted in its history and ethos. It is actually panorama of the aspect and spirit of the English nation that could be seen through the "prism" of Serbo-Croatian interpreters, poets, translators, scholars, of the great Romantic poets Wordsworth, Coleridge, Byron and Shelley, most popular in ex Yugoslav translated literature of all the English poets. The size and the measure of the "prism" of interpreters greatly depended on the circumstances of their own culture and spirit of the time they themselves belonged to, bearing in mind the fact that all translations, except for Byron's works, appeared not earlier than the beginning of the twentieth century century burdened with two world wars, enormous economic crises before and after, provoking social distress worldwide, and accelerated changes in all human fields due to scientific and technological progress.

Jelena Otasevic, Ph.D., Assistant Professor, Faculty of Foreign Languages, University Mediterranean. 
The paper consequently deals with the power of translation regarding reception of a foreign writer into the target culture, and, further on, about the significance translators have regarding impact on the target culture ${ }^{1}$ The power in question has been detected and its strength measured through thorough analyses of the translations of English Romantic Poetry into Serbo-Croatian language, the official language of former Yugoslavia $^{2}$. The analyses actually dug deeply in the period even before the political formation of this state, into period when its peoples were split under foreign rule of Austro-Hungarian Empire and Ottoman Empire, and while still struggling for national liberty through cultural activities in establishing the use of proper language and literature in that language. Such analyses led inevitably to visualizing the English, nation and country, from the translation reader's perspective, as rebellious people, having liberty, equality and patriotism as key values of their society, proud of proper country, due to, partly, translators' misinterpretation and misunderstanding of certain works of some of the romantic poets, and partly due to "premeditated" translations "committed" in order to support the target culture liberal and patriotic aspirations in maintaining proper national pride. The aim was actually to glorify key values of liberty and national pride and to illustrate an example of one such country making some of its poems hymn-like, encouraging proper cultural forces to re-establish proper national identity.

And who is to represent a nation better than its own poets or writers? Literature in general may be very powerful tool for representing a nation or certain culture in its best light. All the spirit, culture and intellectual shape is entangled in a national literature, its history and its future as well. One could not have chosen better to learn about English, nation and its country, than to have an insight in its Romantic era: When the folklore flourished, ethos of a nation, when the new spirit, liberated of all earlier codes was at full-time work, through individual poets' expression, when the Weltschmerz was embodied in a single poets' experience displayed in the everyday language of common people.

And as the famous English writer Dickens says: "It was the best of times, it was the worst of times, it was the age of wisdom it was the age of foolishness..." at the beginning of his famous novel A Tale of Two Cities describing the time of great French Revolution of 1789, it can well be applied in the field of English literature, though he was talking about political and ideological experience. This is the passage between the eighteenth to the nineteenth century viewed from Dickens' perspective in this quote. And if the age of Romanticism was such, considering historical facts and social background, it serves the purpose. Because the pulse of a nation can best be felt in turbulent times, periods of great distress and transgressions from one era to another, when the opposition to the new powerful waves is the greatest, when the waves clash against each other, when the throne is taken by something new and fresh, when the dawn is rising, dawn of New era and when the New Poet was born.

English Romanticism is actually the sum of individual poets' experiences, so different, regarding topics, approach, style. Since it was not a school, or circle, but co-existence of several powerful minds anticipating the power of sub conscience on one side by emphasizing human imagination (Wordsworth and Coleridge), and creating new poetic hero and aesthetic approach through worship of arts and poetry (Byron, Shelley, Keats) on the other, the easiest way to follow the effect made in the target culture was through consideration of

1 Target culture - the term taken from the Translation Studies referring to the culture into which a certain translation is entering ${ }^{2}$ FR Yugoslavia (1918-1990), multinational, multiethnic, multi-religious state created after the First World War (1914-1918), containing six republics, former parts of the great Austro-Hungarian Empire (northern parts-Slovenia and Croatia, parts of Bosnia and Herzegovina) and Ottoman Empire (part of Bosnia and Herzegovina, Serbia, Montenegro, Kosovo, Macedonia); liberty and national identity as unifying principles and of major Interest, independence from imperial past as well. 
translations published in Serbo-Croatian language of each of these individual poets from this group of major five in chronological order.

\section{Poetry of William Wordsworth in Translation Into Serbo-Croatian Language}

The earliest Serbo-Croatian translations of Wordsworth's poetry appeared at the beginning of the twentieth century. Till the Second World War few prosaic translations (of the poems: "Speak!" in 1911, "Lines Written in Early Spring" 1922 and "We are seven" 1927) were published. A few waves of translations in anthologies or reading books followed, intentionally, either for cultural contribution or for education purposes. What is striking is the selection of poems for translation. Lines written in Early Spring had had five translations (1922, 1974, 1978, 1996, 2009); Tintern Abbey Revisited two translations (1974, 1996); Immortality Ode three translations (1974, 1979, 1996); I wondered lonely as a cloud three times (1947, 1974, 1996); one song from the group of songs entitled Lucy poems - A slumber did my spirit seal three times (1947, 1974, 1996); political sonnet Milton thou shoulds't be living two times (1947, 2009); sonnet Upon Westminster Bridge three times (1956, 1996, 2009); and a song with political and historical theme On Extinction of Venetian Republic two times (1978, 2009); Evening on a Calais Beach (1941, 1996 two translations). Songs that had had one translation I travelled among Unknown Men, To Sleep, Solitary reaper, Written in March, France, Conclusion (from The Prelude, Book XIV), London 1802, My heart leaps up, If this great world of joy and pain, The Inner Vision.

All of these are nature poems, or political and historical, and some of them resounding with patriotic tunes. At least, that's what readers of the translations could see. What is obviously missing are poems so characteristic of Wordsworth and so much loved by his homeland readers, poems with true characters and their little destinies such as Goody Blake and Hurry Gill, Simon Lee, Old Cumberland Beggar, Michael, The Idiot Boy, Resolution and Independence or The Leech Gatherer, The Thorn, Her eyes are wild songs of humble and rustic life so called ballad songs. It's The Prelude that is missing in Serbo-Croatian translations and his Excursion, epic form poems, longer soliloquy, poetic autobiography, confession and self-analyses. Excursion contains some ideas already seen in his poems that refer to the influence of the nature to men, and the difference between the childhood and adult age. In the twentieth century Immortality Ode had had its corresponding poetic translation not earlier than 1996 in the work of the poet Luko Paljetak. This song seems crucial for understanding Wordsworth's poetry, his relations with nature and its importance in human's life the absence of which seems an obstacle in understanding complete picture of Wordsworth work.

Serbo-Croatian readership could well imagine beautiful English landscape and countryside, while reading translations of William Wordsworth's poetry; Westminster Bridge and panorama of London, river Wye, Tintern Abbey and its surrounding in his famous songs Upon Westminster bridge and Tintern Abbey revisited; English shores on his return to England full of nostalgic tones for beloved homeland in his song I travelled among unknown men. His regret over fall of the Republic of Venice, its greatness and importance that it had for his own England was seen in the sonnet On the Extinction of Venetian Republic; the poem had had its interpretation too in former Yugoslav languages in the twentieth century. His political sonnets London 1802 and France have given just a glimpse of Wordsworth's personal view of the turbulent French revolution era and English political reaction, as well as his initial revolutionary spirit for the just cause, and further on, his retreat in the good old English shelter from all anarchic threats. His regret for the age of English chivalry, courage, virtue and freedom could well be felt in the translation of his poem starting with lines Milton! thou 
shouldst be living at this hour variously entitled in translations as London 1802 (in 1974 Ranka Kuić's translation) or England (in 2009 Vladimir Jagličić's translation) or simply To Milton (in 1947 translation of the poet Ivan Goran Kovačić).

This was an overall, general view of the image of the English, country and people, and how they were seen in the translations of William Wordsworth's poetry. It seems that translators were inclined to interpret, rather than to translate on some occasions, due to the target culture needs of such literature that would encourage all human virtues such as freedom, courage, strong patriotic feelings, particularly in the period after the World War II during 50s and 60s, crafting in ex-Yugoslavia the cultural and moral guidelines for further national development. In mending the broken pieces of life after the devastating first half of the twentieth century the look of a foreign poet directed towards nature and its significance seemed new and refreshing, his language simple and his feelings deeply human.

Certain omissions, misinterpretations or, maybe in some cases intentional differences from the original are committed out of misunderstanding of the interpreter or his or hers detours of the original on purpose in order to create the image that would fit emotional needs of the multiethnic, multi-religious society of ex-Yugoslavia that was gathered, after very long centuries of foreign domination, under one national anthem and name having common need for freedom, independence and cultural identity as the only unifying factor.

Here are some instances of the misunderstandings of Wordsworth or intentional neglecting of the original message, image or poet's view. The most problematic seems understanding of the translators of the significance that nature had in Wordsworth poetry, his view of its importance for humanity. In his famous sonnet Upon Westminster bridge all of the three translations (of 1956 translator Šunjić Čolaković, 1996 by the poet Luko Paljetak and 2009 and translator Vladimir Jagličić) missed the point in this song - poets admiration for the town (London) at dawn, still asleep and smokeless, actually without smog, lying still in harmony with nature of which itself is a part too, in comparison to industrialization and urbanization needs symbolized by smoke, which will, as soon as it wakes up, disturb the nature's beauty:
A sight so touching in its majesty:
This City now doth, like a garment, wear
The beauty of the morning; silent, bare,
Ships, towers, domes, theatres, and temples lie
Open unto the fields, and to the sky;
All bright and glittering in the smokeless air. ${ }^{3}$

In all of the three translations the word "smokeless" is omitted and substituted with something else. It is clear that all of the elements of the song cannot be transferred into another language through translation and that some elements of the poem have to be "sacrificed" for the benefit of some other elements (on various levels, not just linguistic or poetic). The process of making selection of what to "sacrifice" and what to preserve is known as making hierarchy in the Translation Studies. The success of a translation depends on the translators' skill to decide which element is more important than the other in order to create the same effect in the translation, at least similar to the effect of the original. In the case of this poem key element was not so much the form or description of the image but more important was the word "smokeless" because of the whole chest of meaning it contains - smoke or smog of the industrialized and urbanized England symbolizing the

\footnotetext{
3 "Upon Westminster Bridge", lines 3-8. Cited from: http://www.bbc.co.uk/poetryseason/poems/upon_westminster_bridge.shtml.
} 
decay of humanity not just devastation of the environment. The face of London will change as soon as it wakes up: now still asleep participates in the harmony of nature to which it also belongs to. Our translators failed to recognize the key word, therefore in the translation there is no feeling of opposition - nature versus industrialization. Wordsworth's concept of nature was not understood:

\section{6 Šunjić-Čolaković:}

(...) Otkrite spram poljima

Lađe i kule stoje, crkve i kupole gole,

Miruju pod nebom kao da spokojno mole,

U bistrom zrakujutra sjaje se kao u snima. ${ }^{4}$

1996 Luko Paljetak:

Ljepote jutra: tihi leže stari

Brodovi, kule, crkve, tornji, cio

Taj sklad u polja i svod što se slio;

Sve blista, sja, kroz zrak što čist se zari. ${ }^{5}$

\section{Jagličić:}

Lepote u jutru: nagi mir u duhu,

Hramovi, teatri, kule i plovila

Otvoriše sebe nebu i poljima;

Sve to isijava u dimnom vazduhu. ${ }^{6}$

\section{Back-translation:}

(...)Unveiled towards fields

Ships and towers, churches and domes, bare,

Stand still under the sky as if in a peaceful prayer,

In the clear air of the morning shine as if in a dream.

Back-translation:

Morning beauty: they are quiet - old

Ships, towers, temples and domes; the whole

That harmony driven in the fields and sky above;

All shiny, glittering, through the clear air brighening.

\section{Back-translation:}

The morning beauty: bare peace in spirit,

Temples, teatres, domes and naves,

All opened towards the sky and fields:

Everything glowing in the air full of smoke.

Anyway, it is the beauty of London, the town that is emphasized in these translations, despite the omission of the word smokeless so familiar to the Wordsworth's philosophy of nature. But in 2010 one Serbian translator, Dragan Purešić ${ }^{7}$, made necessary corrections regarding aforementioned line containing the word "smokeless":

\section{Dragan Purešić:}

Grad ovaj sada odoru prima

Lepote jutra; u miru sa svima.

Brodi, tornji, kule, crkve, od njih svako

Širi se po zemlji, i nebo bi takô;

Svetlucavog sjaja, u zraku bez dima.

\section{Back-translation:}

This town now doth a garment wear

Of the beauty of the morning, in peace with all.

Ships, towers, domes, temples, each of them

Stretched on the ground, inclined to touch the sky.

With a marvelous glow, in the smokeless air.

Further on, in the final line of the poem, the poet personifies the river (saying that it "glideth at his own sweet will" and by using the expression his own as if it is a living being, and using his instead of its for innate subjects) and personifies the town (London) by saying that the town "seems asleep" together with its "mighty heart", offering us an image of an industrialized urban site, more like a beast at rest; in the 1956 translation $^{8}$ this personified image of the river lying still, as well as the town, and its mighty heart becomes an image of the heart of the world, not of London, therefore forcing the reader to dislocate its view towards the world, not London:

4 "Na Vestminsterskom mostu”, trans. Šunjić-Čolaković (Ježić, Krklec 1956, 504).

5 "Na Vestminsterskom mostu" (Paljetak 1996, 88).

6 "Na Vestminsterskom mostu" (Jagličić 2009, 179).

${ }^{7}$ Purešić, 2010.

8 Ježić, Krklec, 1956. 
1956 Šunjić-Čolaković:

A moćno srce svijeta smirenim ritmom kuca. (Orig. And all that mighty heart is lying still).

(And the mighty heart of the world beats in a moderate manner) ${ }^{9}$

And as is obvious, the heart in this translation beats, it is not "lying still". Another breaking of the original sense betrays Wordsworth's intention to oppose to each other nature, even in an urban site, and industrialization, so obvious in the original.

In the 2009 translation ${ }^{10}$ "that mighty heart" of the town becomes the heart of the poet ("na mom srcu celom leži isti mir", eng. at my heart the same peace is laid upon); and in 1996 translation $^{11}$ the river is personified too ("Rijeka po svojoj miloj volji bježi", eng. river flees as if in its own will), and the mighty heart is at its place ("I svo to moćno srce mirno leži", eng. and that entire mighty heart is lying still). The translation from 2010 of Dragan Purešić confirmed the 1996 version, in its last line, preserving the same figure of speech in the translation.

One of the reasons for the listed omissions lays probably in the fact that industrialization and the problems that went hand in hand with it were not familiar to the target culture due to the differences of the technological development of the two countries: England and ex-Yugoslav republics. It seems that the 20th century translators' intentions were to display Wordsworth's poetry to the Serbo-Croatian readership in the manner in which they themselves understood it. Nature as a device for comparison and outlining contrast to the rising industrial and materialistic society and deterioration on human life due to industrialization are neglected partly because of misunderstanding of the interpreters or partly because of the image of the English needed by the target culture to be the pillar stone for the proper cultural and national growth.

Wordsworth's description of nature is never only pure image, a sight in front of him. Ifor Evans summarizes about all Romantic poets: "they all had a deep interest in nature not as a centre of beautiful scenes but as an informing and spiritual influence on life". ${ }^{12}$ And as Pat Rogers puts it about Wordsworth: "In the poem the poet's thoughts proceed from external description to a moment of illumination as he reflects on true nature of life he is observing". ${ }^{13}$ Wordsworth's "emotions recollected in tranquility" are stimulated by nature and then "related outwards" events surrounding England during and after the French Revolution in 1789, and due to poet's activities related to that political issue, Wordsworth used the sonnet "to arouse England to a sense of her responsibility in international affairs, and to express poignant moments in his own experience". ${ }^{16}$

English panorama, the image of its people and country created thanks to the translations of certain Wordsworth's poems into Serbo-Croatian culture was such due to specific selection of poems for translation too. If we take a look of the titles one can easily see that some poems have had several translations in the 20th century, whilst the others haven't had a single one. The country, former Yugoslavia, exhausted by two world wars, destroyed physically and morally, was in need in post WWII era of the impetus, encouragement on the

\footnotetext{
9 All the words in the translation of the 1956 translation correspond to the personified image of the town.

10 Jagličić, 2009, p. 179.

11 Paljetak, 1996.

12 Evans, 1970, p. 366.

13 Rogers, 2001, p. 286.

14 Sanders, 2004, p. 363.

15 Ibid, p. 363.

16 Evans, 1970, p. 71.
} 
road of the proper restoration. It seemed apposite to teach children at schools, as well as students at universities of basic human virtues and make it their own goal. It was, therefore necessary to emphasize those romantic poetry messages of such kind. Wordsworth appeared in two anthologies of the world's poetry in $50 \mathrm{~s}^{17}$ and in the Serbian anthology of the European Romantic Poetry in $1978^{18}$. In all of the three anthologies one could find either nature poems of Wordsworth or those with historical and political background.

Another specific feature of the Wordsworth's poetry in translation into Serbo-Croatian language is that the majority of the translated opus has been actually the result of the work of the three Serbo-Croatian translators, Ivan Goran Kovacic, the poet whose poems were translated posthumously in $1947^{19}$, immediately after the World War II, then Ranka Kuić, renowned Serbo-Croatian scholar, whose translations were published in 1974, in the midst of communist ideology at work, and Luko Paljetak, Serbo-Croatian poet and translator whose work was published in $1996^{20}$, in the decade when Yugoslavia was already dead. Two anthologies of the translated poems of the English Romantic poets were published in the twentieth century, containing the poems of William Wordsworth: Antologija engleske romantičarske poezije (Kuić, 1989), and Antologija pjesništva engleskog romantizma (Paljetak, 1996); but some of the songs included in these anthologies were translated several more times in the course of the century. There was published the third anthology, including a list of William Wordsworth poems in 2009, Danse Macabre (Jagličić, 2009) and Blejk-Berns-Vordsvort-Bajron-Šeli-Kits, Poezija engleskog romantizma (Purešić, 2010).

The poems selected for translation and even translated several times also witness the sympathies and inclinations towards those Wordsworth's songs resounding patriotic tunes or glorification of the human virtues. In the "Sonnets dedicated to Liberty" published in 1807 collection Wordsworth wrote about consequences of the French foreign policy, on corrupt and selfish English present and on nobler goals of the Civil War. In the poem On the Extinction of the Venetian Republic, a poem from his "Sonnets dedicated to Liberty" published in 1807 collection (Sanders, 2004, p. 365) (the translated versions into Serbo-Croatian 1978 Pavlović-Simović, 2009, Jagličić) Wordsworth expresses admiration for something magnificent, such as a historical point of time, the power and significance of a mighty realm that once existed, and "even the Shade / Of that which once was great is passed away". Wordsworth's lament over its disappearance seemed apposite for translation in a communist country such was former Yugoslavia, having tendencies to glorify political greatness, and it served the purpose as an example of the stable and strong country particularly bearing in mind that central and southern-eastern regions of the Serbo-Croatian realm were under Ottoman Empire for five hundred years, and a song about the Republic which "once did she hold gorgeous East in fee" seemed as a reverie on those hard times of the proper national history.

In the poem London 1802, composed in 1802 and first published in Poems in Two Volumes (1807) Wordsworth speaks, in almost reproachful voice for the English people, of the renowned seventeenth century poet John Milton, and it sounds like a sort of homage to Milton, but actually seems to point a finger towards problems of the English society. English are, indirectly criticized for being rather too selfish and static in comparison to Milton's era and Wordsworth indicates the problems of English society. He says England was once the country of chivalry, place of happiness, faith, art and literature and that at present those virtues have

\footnotetext{
17 Ježić, Krklec 1956.

18 Pavlović, 1978.

19 Kovačić, 1947.

20 Paljetak, 1996.
} 
been lost. This song had had several translations in Serbo-Croatian language. But here, too we have an example of misunderstanding of Wordsworth concept of nature's significance for men. Wordsworth compares Milton to a star, sea, heavens - nature concepts which have for Wordsworth a particular significance. Natural objects are divine, therefore to be compared to it is a compliment and adds to the significance to the person that is compared with it. This has been neglected in 1974 translation $^{21}$ and the translator omits to compare Milton to a star, thou the other two comparisons to nature objects respects almost faithfully-to sea and heaven:

\section{Wordsworth:}

Thy soul was like a star, and dwelt apart;

Thou hadst a voice whose sound was like the sea;

Pure as the naked heavens, majestic, free...

\section{Ranka Kuic (and back-translation):}

Tvoj duh svetli sa svojih visina

Tvoj glas grmi kao zahuktalo more,

Čist, slobodan, veličanstven kao nebo.

(Your spirit is glowing from its heights

Your voice is a roaring stormy sea,

Pure, free, majestic, like heaven).

In an earlier translation from 1947 by Croat poet Ivan Goran Kovacic ${ }^{22}$ and in the most recent, 2009 of a Serbian poet translation ${ }^{23}$ all of the three original images are well preserved - Milton like a Star, Sea and Heaven.

Despite new technologies or better knowledge of the English language and culture worldwide and its wide use, in the 21 st century there were two more editions that published several Wordsworth poems in Serbian language, in anthologies of romantic poetry and regretfully with no translation of his ballad like songs of individual human destinies such as Hurry Blake and Goody Gill, Yaw Tree, Idiot boy, Old Cumberland beggar, Michael, and others or his Prelude or Excursion. Immortality Ode had had one translation in its entirety in 1996 in a Croatian edition of the poet Luko Paljetak. The translation is glowing with full shine of Wordsworth's figures of speech preserved in the translation, carrying in it all the deeper messages sowed inside.

Critic John Purvis comments that Wordsworth is commonly bowdlerized into a "Nature poet" and his frequent accounts of human beings in economic difficulties are dismissed as his "revolutionary growing pains" - to be omitted from the safe anthologies in which he is commonly presented to the adolescent mind (Purvis, 1990, p. 55).

But despite this it seems quite curious and unusual, from Serbo-Croatian perspective or cultural ground, that so-called ballad like songs of individual tragedies in society, the sufferings of old age, poverty and desertion were not of the particular interest for the translation, since the literature of Serbo-Croatian nations had had similar forms in its own folk ballad like verse tales in their literary tradition. Not a single poetic translation appeared in the twentieth century. Only in 2009 did Andrew Jones appear in a witty translation of Serbian poet Vladimir Jaglicic. Perhaps too late. The image of Wordsworth as nature poet in the target culture was already cemented.

\footnotetext{
${ }^{21}$ Kuić, 1989, p. 155.

22 Kovačić, 1974, p. 23.

23 Jagličić, 2010.
} 


\section{Imaginative Poetic Creation as an Expression of Liberal Mind in the Poetry of S. T. Coleridge in Translation}

The English Poet S. T. Coleridge was dominantly known for his magical creations in the two of his most beloved poems: Kublai Khan and The Rime of the Ancient Mariner. His task within Lyrical Ballads was to write about unusual things, according to the agreement with William Wordsworth, his friend and coauthor of the book. And he fulfilled his task: the 15th century Mongolian leader Kublai Khan and his garden with "sinuous rills" and unpredictable river Alf sound miraculous enough even today, both of which, most probably symbolize an innate human power of imagination, and I would say, in the terms of modern psychology, an unconscious human powers (powers of human mind) yet to be discovered. The same can be said for the other great poem, The Rime of the Ancient Mariner: its narrator and main character telling us about his voyage through dangerous seas and unpredictable weather was, most probably, talking about human voyage through life. It is after the Mariner shoots the albatross that he enters a sea where no one else has been. From here on we realize that we are dealing with the fate of an individual human being rather than that of the crew (Jackson Bate, 1987, p. 60). Motive chain based on Christian religion - sin, penitence and forgiveness - that is holding this story so strongly as a spine holding human body vertically upright, is authentically jeweled with miraculous supernatural beings, fantastic scenery and endowed with universal messages of accepting the destiny no matter its course and of being thankful to it whatever happens in our lives. The poem Cristobel comes in line with miraculous inclinations of the poet describing magical appearance of the lady Cristobel but its rather the scenery and some mysterious expectation that is felt rather than the character itself being mysterious.

Regretfully, Coleridge was modified to fit the needs of the ex-Yugoslav readership and, more general, the needs of culture in newborn communist country. Magical, at moments sparkling, somewhat veiled and oracular, Coleridge's poetry in translation into Serbo-Croatian language of the twentieth century ${ }^{24}$ (not earlier was he present in translation) was appropriate enough to display varieties of the artistic world to be enjoyed and for communist Yugoslavia, the world of culture for those in need of spiritual and mental refinement. But such strong communist and, subsequently atheist doctrine, prevented Coleridge to be fully and properly presented to the ex-Yugoslav audience in the twentieth century due to the fact that his major work "The Rime of the Ancient Mariner" was deprived of its religious motive of sin-penitence-forgiveness chain in its translation. He was also made to be seen as a poet with liberal views thanks to omission of the word "Britain" in his The Fall of Bastille poem glorifying human freedom of any kind of tyranny with the probable tendency of making it more universal poem. The selection of his poems for translation also add to the conclusion that Coleridge's poetry was subject of adjusting in order to be in line with the needs and scopes of the target culture - justification of suffering and victims of the WWII and cultural support to the politics that enabled creation of free and independent state, Socialist Federal Republic Yugoslavia.

The greatest contribution to the translation of Coleridge's poetry into Serbo-Croatian language was given by Serbian scholar and Anglicist Ranka Kuić. Her anthologies of English literature in translation are still used in classrooms as textbooks and her translations, because of their style and refinement, still read and reprinted today. Her anthology of S. T. Coleridge's poetry in translation was published in $1969^{25}$ and her anthology of

\footnotetext{
${ }^{24}$ The first translation of S. T. Coleridge's poetry appeared into Serbo-Croatian language not earlier than 1911, in Bosnian magazine Bosanska vila, XXVI, no. 7-8, p. 106. It was his song Work without hope.

${ }^{25}$ Kolridž, 1969.
} 
English romantic poetry in $1974 .^{26}$ Here particular focus is made on the dates of publishing these translations because 1970s were the decade of the highlight of communism and enthusiasm regarding union such was Yugoslavia. Kuić was admired and lauded for her interpretational skills, yet it is in her translation of the Ancient Mariner that the religious concept of sin-penitence-forgiveness is missing, actually, transformed into something else. A voyage of an old mariner with his companions turned down to be a voyage to hell and back because the mariner shot and killed albatross on impulse, an act which announced bad luck. In the sixteenth stanza of the part I, the poet says that in an obscurity of the fog in an unfriendly environment colored by bad weather and ice all around there it came an albatross "the Christian soul" and "it was hailed in God's name" by the sailors. These two religious components are lost in translation or, were translated in the spirit of communist (atheist) ideology:

\section{Coleridge:}

At length did cross an Albatross,

Through the fog it came;

As if it had been a Christian soul,

We hailed it in God's name.
1969Ranka Kuić (and back-translation):

Al' kad na brod sleti na pod

Tad albatros kroz mrak,

K'o da je nama svima brat,

Tad pozdravi ga svak.

(When it landed on the deck

The albatross, through the dark

As if it was brother to us all

Was hailed by all of us).

The word "brother" instead of "the Christian soul" suggests the aforementioned intentional change of one word with another. In the second part the same change takes place, depriving the poem in translation of the initial motive - the Sin:

\section{Coleridge:}

Ah! well a-day! what evil looks

Had I from old and young!

Instead of the cross, the Albatross

About my neck was hung.
1974Ranka Kuić (and back-translation):

I mrko me je gled'o svak:

Mlad mornar i s njim star,

Na vrat mi mrtvu pticu, vaj

Tad stavise k'o dar.

(I was frowned at by all!

By young as well as old sailors!

About my neck the dead bird

Was hung as a gift).

The poem's close relationship with religion is clearly stated by the poet himself - as Jackson Bate quotes Coleridge: "I believe most steadfastly in original Sin; that from our mother's wombs our understandings are darkened and even when our understandings are in the light, that our organization is deprived, and our volitions imperfect" (Jackson, 1987, p. 60).

By loosing the religious motive in the translation, the character of the Mariner himself, his motive for killing the bird is lost too. He is supposed to be strange, a man on impulse, people should be "beware" of him, "a frightening figure", the impact of whose experiences unsettles ordinary life (Rogers, 2001, p. 292). Jackson

\footnotetext{
${ }^{26}$ Kuić, 1974.
} 
Bate too confirms that the Mariner's theme is the nakedness of man's trembling existence before the vast unknown, an existence made the more vulnerable by what Coleridge in a later poem called "the unfathomable hell within" (Jackson, 1987, p. 60). And yet, Mariner in the translation of Ranka Kuić puts in front line the "comradeship", union and the crew - social rather than individual. So it is not just the omission, but the use of a particular word also to confirm such conclusion of ours of intentional avoidance of the original motive. It is considerable loss, anyway.

Similarly, Ranka Kuić avoided the word "Britain" in the translation of Coleridge's poem The Destruction of the Bastille, in the last stanza and obtaining that way universal hail resounding with patriotic melody:

Coleridge:

And still, as erst, let favour'd Britain be

First ever of the first and freest of the free!
1974Ranka Kuić (and back-translation):

I nek tada narod moje rodne grude

Od slobodnih prvi sav slobodan bude!

(And let then my countrymen

Become all free, before others!)

The song composed in the year of great French Revolution in 1789 following destruction of the Bastille was actually the song describing Coleridge's feelings of hopes for the French Revolution as a catalyst for political change $e^{27}$. In the last stanza of the poem The Destruction of the Bastille the narrator asks the Prime Minister of Great Britain to help Belgium break free of Austrian control, and the poem ends with an emphasis on Britain having already experienced a revolution centuries before. In the translation Coleridge's moderate views are somewhat sharpened and translation is written in the spirit of target culture national folk poetry, rhymed and hymn-like to glorify freedom, brotherhood and patriotism. It was suitable enough for the actual political moment in the country.

Finally, the selection of Coleridge's poems for translation made by Ranka Kuić was subjective rather than all-inclusive. What I mean by this is that it is obvious that songs from Coleridge's opus were selected to fit the subtitles of the chapters and the chapters were made to show the variety of Coleridge's work regarding themes, motives, poetic style. Though, we today know that he is primarily esteemed for his dream-like poems and fragments such as "Cristabel", "Kubla Khan", or the "Rime of the Ancients Mariner", criterion by which Kuić selected some of his poems of no particular poetic value in comparison to some other songs of his was rather for their topics and context. Here are the titles of the chapters in her 1969 anthology of Coleridge's poems: "Romantic Poems", "Personal Poems", "Political Poems", "Humorous and Satirical Poems", Attachment with quotes from Coleridge's Prose Works. Poems in the chapter entitled "Political Poems" include: "The Destruction of the Bastille", "Pantisocracy", "La Fayette" and "Ode to the Departing Year". This selection is suggestive enough. It is well known that Pantisocracy is the poem representing Coleridge's ideal place of freedom and equality, an escape from the troubled materialistic world, celebrating all the values considered to be fundamental within former Yugoslavia communist regime; further on, La Fayette is the song about the French Lieutenant and hero of two revolutions for independence - American 1772-1776 and French 1789, anti-tyranny rebel against any form of oppression; and in the Ode to the departing year Coleridge expresses his political and religious views, and by seemingly celebrating the death of Catherine of Russia whom he believed to be alleging against France and freedom of less powerful European countries, the poem is actually putting an emphasis on the suffering of mankind, slavery, poverty and oppression - injustices for materialistic reasons.

\footnotetext{
${ }^{27} \mathrm{https}$ ://en.wikipedia.org/wiki/The_Destruction_of_the_Bastile, 11/04/2016.
} 
Liberal inclinations of an English poet are to be seen in the translations of Coleridge's poems thanks to the great contribution of the Serbian scholar, translator, university teacher Ranka Kuić. Her soft poetic sentence and her verses appealed to the Serbo-Croatian readership in the country extending all the way from the Greek borders to Austria and Italy. Her translations were used and read at various universities and English language departments of former Yugoslavia, in Sarajevo as well as in Zagreb or Belgrade. Her immense talent and creative spirit enabled generations of English language and literature students to meet and enjoy abundant poetic imagery of "Kublai Khan" garden; the glittering of the sea and snakelike creatures and other supernatural beings; apparitions in "The Rime of the Ancient Mariner", and through Coleridge's reveries of the seasons and landscape of English countryside, the poet's birth place in "Frost at Midnight".

Full and adequate translation of "The Rime of the Ancient Mariner" appeared not earlier than 1994, by Natasha Tučev Serbian scholar and translator that amended the earlier work of Kuic. In Croatia there was published translation of the "Mariner" in 1996 by Croatian poet and translator Luko Paljetak that can also be considered to have followed the line of the original religious motive chain. Anyway, one mustn't blame or criticize Kuić for the change of the original motive. It was probably the best way to present to Serbo-Croatian readership the English poet whose literary universe was rather too complicated to understand otherwise - such summary of Coleridge's work given by Kuić was fit enough just to give an insight of the variety of his work and interests. This way English poetry was well displayed as a reflection of ideas revealing this magic of creation, in more artistic way and less didactic - or moralizing. Thanks to her choice of Coleridge's poems for translation these ideas of freedom and revolution were seen as prerequisites of more humanized society, and the English people as just and emphatic.

\section{Individual and National Liberty More Precious Than Noble Rank for Lord Byron in Translation}

An English nobleman giving up of his wealth to go and fight for Greek's freedom and liberation of Turks was probably the best known fact about George Gordon Noel Byron in Balkans, the most famous English Romantic poet among South Slavs; and not just them. Lot of people around Europe were experiencing the wake of national pride in 1840 s, since Europe, at that time was divided among great European powers, particularly Balkans, where Slavs were serving under two powerful Empires: Austro-Hungarian and Ottoman Empire. Therefore, powerful feelings of oppression and tyranny were fresh wounds among ex-Yugoslav peoples split under the rule of these two Empires and the character of Lord Byron, coming from abroad, and the facts about his personal little rebellion were far more popular even before his poetry reached its translation versions. Byron the libertarian and Byron the libertine readily assumed the public role of a commentator on his times because he both relished his fame and enjoyed the later Romantic pose of being at odds with established society (Sanders, 2004, p. 383). His liberal mind and glory were powerful impetus for all those Serbo-Croatian intellectuals studying at major European universities, intellectuals to appear later as major creators of so called Illyrian movement ${ }^{28}$ that has stirred cultural and national resistance to oppressors, the resistance that anticipated real war for independence, diplomatic, at first, but later military, provoked by the shooting and killing the Austrian

${ }^{28}$ The Illyrian movement (Croatian: Ilirski pokret, Slovene: Ilirsko gibanje) was a pan-South-Slavist cultural and political campaign with roots in the early modern period, and revived by a group of young Croatian intellectuals during the first half of the 19th century, around the years of 1835-1849 (there is some disagreement regarding the official dates). This movement aimed to create a Croatian national establishment in Austria-Hungary through linguistic and ethnic unity, and through it lay the foundation for cultural and linguistic unification of all South Slavs under the revived umbrella term Illyrian. 
heir to the throne France Ferdinand in Sarajevo in 1914 that led to the outburst of the First World War. Centuries long foreign dominance in the territory of ex-Yugoslavia and its peoples increased the rebellious mind and their pains found its relief and voice in the character of an English bard, moreover, a Lord that had sailed many seas, visited these poor Slavic areas of Adriatic coast to finally decide to sell everything he owned, to despise what was erroneous about his nation's foreign policy and to go to fight for freedom of the oppressed. His poetry is informed not by nature or by contemplation of nature, but by public life and by recent history, by British politics and by feverish European nationalisms stirred by the French Revolution (Sanders, 2004, p. 383).

Major contribution regarding the reception of Lord Byron in former Yugoslavia was given by Ilija M. Petrovic and his study "Lord Bajron kod Jugoslovena" (Lord Byron in Yugoslav Literature). ${ }^{29}$ Byron was the first, and almost the only English Romantic poet that has been translated in the nineteenth century in ex-Yugoslav language. In the target culture, i.e., Serbo-Croatian, at that time, when Byron died and was very popular in other parts of Europe, circumstances were such that it was too early for any foreign writer to enter it, since there were no domestic ones to publish:

At the time when Byronism began to flourish in the greater European literatures, Yugoslav literature was still in its first stage of revival. For nearly four centuries Yugoslavs struggled against the Turkish invasion from the south and against German and Hungarian aspirations in the North. During that hard period of fighting for mere existence, there was practically no national or cultural development among the various Yugoslav groups. (...) But the birth and triumph of the nationalistic idea at the beginning of the nineteenth century had a considerable influence on the Yugoslav nation. National consciousness was awakened among them, and a renewed struggle for freedom started with great vigor, associated with an attempt to build anew the civilization of the people.

In the year 1824, when Byron died, there had been printed in the various Yugoslav dialects (Serbo-Croatian and Slovenian) not more than two or three score-books, mostly of a religious and educational character, with only one or two among them that could be counted as a contribution to real literature. ${ }^{30}$

His influence and presence in Yugoslav cultures was in the nineteenth century mostly indirect, through legends and biographic moments of his particular, misanthropic character, and through scarce number of translations, limited majorly to his verse tales that were particularly interesting for the nineteenth century readership for being placed on an Oriental or other exotic location, and the plot that was keeping reader's full attention. It was the contents of the tales rather than the form that attracted the attention of readers (Kićovic-Pejaković, 1973, p. 262).

After the year 1900, and contrary to the nineteenth century interests, Serbo-Croatian readers were becoming more and more familiar with Byron's lyric poetry, shorter poems and excerpts from his longer poetic works thanks to the selection made by translators. This shift from popular verse-tales and their exotic ambience meant, most probably, the sobering from the enchantment made by Byron's own character and sobering from the influence of the literary fashion occupied by so-called brand new "Byronic" hero. This obvious difference between the nineteenth and twentieth century regarding Byron's poetry in translation involves many reasons. The poet's reputation, after Byronism had expired silently in ex-Yugoslavia as Ilija Petrovic claims by the end of the nineteenth century ${ }^{31}$, was becoming more and more reliant on his pure lyrics and universal literary values

\footnotetext{
${ }^{29}$ Petrović, 1989.

30 Ibid, p. 227.

31 "If Byronism disappeared in other literatures in contemptuous ridicule and scorn, in Yugoslav literature it has died out slowly by itself, gradually and in silence, almost without a direct word of protest from anyone in authority, and not until the end of the century" (Petrović, 1989, p. 228).
} 
of his poems. It is probably best evident in the number of translations of the three Byron's very popular poems: When we two parted (4 translations), So we'll go no more a rowing (4 translations), and She walks in beauty (6 translations).

The autobiographic poem On this day I complete my thirty-sixth year has had nine translations into Serbo-Croatian language in the twentieth century; it was printed and reprinted in various textbooks and anthologies, it was very popular and suitable enough for the young to learn about some of the most important human feelings: liberty and patriotism. This song, containing typical Romantic contradiction between sad resignation and rebellious liberalism, served well enough the purpose - to promote liberty, in general, to heal the wounds made by five century long dominance of the Turks in this part of Balkans and, finally to display identity doubts and crisis of the personality so common for the young people. Namely, the song was written on the occasion indicated by its title: on the completion of the poet's thirty sixth year. Actually it was written some time before and served as a kind of prophesy in the poet's real life. He really died three months later after he had completed the song. It was particularly interesting for Serbo-Croatian readership because of the facts preceding its creation: Byron wrote it while in Greece in January 1824, preparing to take part in the Greek revolution for freedom against Ottoman Turks, the very same enemy that Serbs had had for centuries. An English lord who had sold everything he had to fight the war for freedom of the conquered people echoed louder than any of his songs in the mind of the suffered peoples of ex-Yugoslavia. The battle field wounds of the WWI and WWII were still recent reality, the country still in economic crises and in its restoration phase requiring lot of moral strength and courage, its cultural life in need of new contents in line with dominating doctrine of communism, at the time when majority of translations of Byron's poetry were published - 1960s and onwards.

Byron's verse tales were very popular and majority of them were translated in the nineteenth century; but, in the twentieth there was only one verse tale of particular interest to Serbo-Croatian translators: The Prisoner of Chillon. It was actually Byron's A Sonnet to Chillon that had had four translations into Serbo-Croatian language; it was not the tale itself that was interesting for translation, since there is none yet, but the Sonnet starting with famous words: "Eternal Spirit of the chainless Mind! / Brightest in dungeons, Liberty!" One can only imagine how important these words were for the Yugoslav peoples at that time, bearing in mind its history, since three translations were published, and three reprints: $1947^{32}, 1952^{33}, 1954^{34}, 1965^{35}, 1968^{36}, 1974^{37}$.

Byron's lengthy narrative poem Childe Harold was of particular interest for Serbo-Croatian translators in the twentieth century. There were three translations of the entire poem: $1965^{38}, 1978^{39}$, and $2004^{40}$. Some parts of the poem were translated throughout the century, some were repeated, but it is the selection of particular parts of the poem for translation that indicate translators inclinations of creating an image of Byron that would suit ex-Yugoslav cultural emphasis on freedom and patriotism. It seems as if translators were particularly picking those parts containing such indications, and there are examples of translations bereaved of any

\footnotetext{
32 "Slobodi", trans. Ivan Goran Kovačić, 1947.

33 "Sonet slobodi", trans. Kuić, 1952, p. 231.

34 "Sonet slobodi", trans. Kuić, 1954.

35 "Sonet o Šijonu”, trans. Aleksandar Spasić, in: Đurić 1965.

36 'Šijonskom suznju', trans. Ranka Kuić, in: Pavić, 1968.

37 "Sonet slobodi", trans. Ranka Kuić, 1974; this book also had four later editions containing the same song, in $1981,1986,1989$.

38 "Hodočasće Čajlda Harolda", trans. Danko Anđelinović, in: Bajron, 1965.

39 "Čajld Harold", trans. Paljetak, in: Bajron, 1996.

40 "Čajld Harold”, trans. Nataša Tučev, in: Bajron, 2004.
} 
particular names or locations mentioned in the original in order to make the excerpt look more general, fit to any place and time as universal message to humanity. Lyric insertion in the first Canto of Child Harold "Adieu, adieu! my native shore" was particularly popular and had had several translations into Serbo-Croatian language. Harold's departure and his regret for leaving his native land, and further description of his castle never to be seen again, were images beautifully and faithfully transferred into translations in $1900^{41}, 1966^{42}, 1975^{43}$.

There were other parts of the Childe Harold's Pilgrimage that were translated into Serbo-Croatian language in the course of the twentieth century. In 1920s famous Serbian poet, writer and translator, Isidora Sekulic wrote an article "Popular revolt in Greece and the English poet Byron" published later, in 1957 in her collection of essays "Mir i nemir" (Nolit, Beograd). In the essay she writes about Byron and, at the same time inserts translations of some of his songs, among which we may find excerpts from his Childe Harold's Pilgrimage, the first stanza from his "Adieu, adieu! my native shore"; further on, from Canto II LXXII (lines 1-2 from stanza 1, and stanza 11); LXXIII (lines 1-4), LXXIV, LXXV (lines 7, 8, 9); LXXVI; LXXXIII (lines 7-9), LXXXIV. This particular selection, when read in this new compilation, illustrates liberal mind of the author, an open revolt against oppression and, at the same time it is a sort of hail to freedom in general. If we take a look of the selection of fragments put together we can notice clearly the intention of translator and the impression of the reader - it is an open call to fight for freedom:

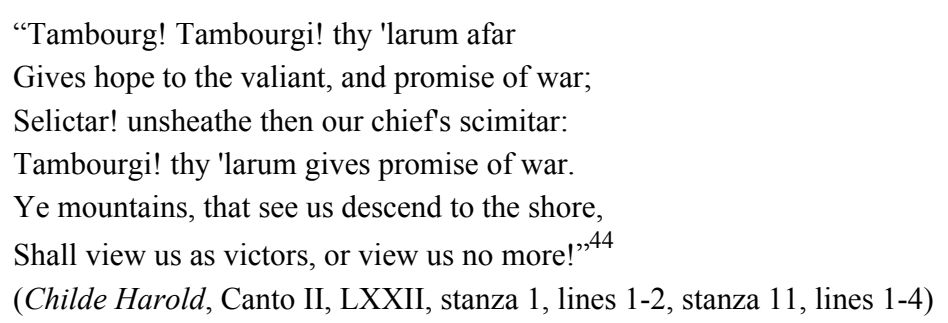

The translator has made completely new stanza taking some lines (1-2) from the first one and the whole final one - stanza eleven, avoiding to translate particular names of the people mentioned in the original, probably in order to make of it somewhat more general or universal message. Reader of this translation is not aware of the omission which quotes: "All the sons of the mountains arise at the note, / Chimariot, Illyrian, and dark Suliote ${ }^{45}$ !". The intended readers of this translation Serbo-Croatians were Illyrians by origin, not to mention that the other two nations in this citation were Christians ruled by Turkish Muslims for centuries. The translation of these fragments was published for the first time in 1924, in the period between the two World Wars, and reprinted several times later during the century.

Such tendency of making Byron's verses from Childe Harold look more general and avoidance of mentioning particular names and locations specifically indicated in the original can also be found in the translation of the fragment from Canto IV, stanzas CXL, CXLI, published immediately after the World War I in 1918. in Serbian magazine Ratni dnevnik ("Wartime diary") from Valjevo. The very name of the magazine is

\footnotetext{
41 “Iz Čajld Harolda, Laku noć”, trans. Th., Gradina, 1900, I (1), pp. 3-4.

42 "Laku noć", transl. Đukic Trifun, in: Đukić 1966.

43 “Čajld Harold”, transl. Sekulić Isidora, in: Mijušković, Filimonović (eds.) (1975) Poezija i kritika, Beograd: Nova knjiga.

44 Byron, Childe Harold, citation taken from the website http://knarf.english.upenn.edu/Byron/charold2.html on 11/28/2016.

45 The Souliotes were an Orthodox Christian community of the area of Souli, in Epirus, known for their military prowess, their resistance to the local Ottoman ruler Ali Pasha, and their contribution to the Greek cause in the Greek War of Independence, under leaders such as Markos Botsaris and Kitsos Tzavelas. citation taken from the website https://en.wikipedia.org/wiki/Souliotes on 11/28/2016.
} 
quite illustrative for the topic and motives. Byron's original is written in the first person, revering the glorious days of the Roman Empire when gladiators fought in an arena, bleeding and dying, for the amusement of their audience. In the translation we see a hero, wounded and bleeding on the battlefield, yet silently suffering his pain, thinking only of an old cottage on the bank of some village river. We can see around him a battle going on, as he even hears sling bullets flying around him. In these stanzas the original says "I see before me the Gladiator lie", which the translator interprets as "I see a hero lie before me, knocked down". The original says "the arena swims around him - he is gone/Ere ceased the inhuman shout which hailed the wretch who won": the translation says "behind and in front of him there's the battle echoing sound, he dies, and in a few moments the destiny of his nation will be decided". In the original work, the Gladiator thinks only of his "rude hut by the Danube/There were his young barbarians all at play/There was their Dacian ${ }^{46}$ mother - he, their sire, / Butchered to make a Roman holiday". The translation says that the hero sees his village cottage by a river, his children playing and their mother caressing them while he, their father, dies here for the sake of the native land. No mention of Romans and the hail for the other "wretch" who won in that duel. The intention of the translator is clear.

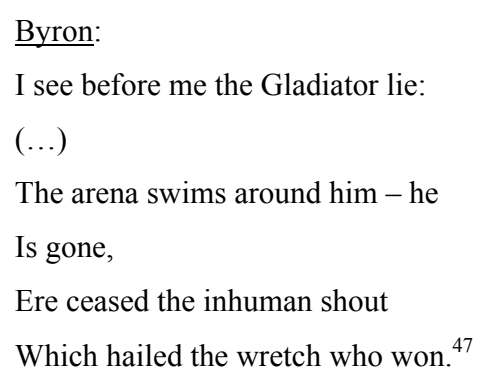

B. A. N. (back-translation):

I see a hero knocked down in front of me:

(...)

Around him the battle echoing -

He dies,

In a few moments the destiny of

his nation will be decided.

There were two translations into Serbo-Croatian language of The Battle of Waterloo part from Childe Harold in the twentieth century. The quote from Canto III, the one describing the battle and the preceding evening was of particular interest for translators and readership as well due to the number of reprints. Courageous and merry men and ladies celebrating in the eve before the battle were displaying the fervor of the oppressed so truly experienced and familiar to the ex-Yugoslav readership. The description of the battle, very convincing, as if experienced by the author himself, seemed apposite for translation in the ex-Yugoslav context of the post World War II decades. In 1959 it was published the translation from Byron's Childe Harold under the title "On the Eve of the Battle" in the Prishtina's magazine Jedinstvo. The following stanzas were translated in verse: XXI, XXII and XXIV. Remarkable lyric and style of the translation offers to the reader the rush, the sounds, the images and the impression of the immediate battlefield danger, and the translation itself, when read as a separate authentic work, stands as if it were not translation of some foreign poem but it rather echoes as if originally written in Serbo-Croatian language. It was the translator's inspiration and creativity to pronounce Byron's words in more vivid tone, and, at the same time, presented the English as courageous people with liberal mind able to stand up for the just cause and proper country.

\footnotetext{
${ }^{46}$ Slaves who were captured in conquered countries, in this case Dacia, a Roman province from the second century A.D., were taken away from their families and lives to be sacrificed for Roman aristocratic amusement.

${ }^{47}$ Byron, Childe Harold's Pilgrimage, Canto IV, stanza CXL, lines 1, 8, 9, http://knarf.english.upenn.edu/Byron/charold4.html, $11 / 28 / 2016$
} 
The very same message about the English, actually the British, was sent by the 1974 translation of the piece from Childe Harold Canto III, which was published in an Anthology of English Romantic Poetry ${ }^{48}$ by Ranka Kuić, translator, editor and writer. She translated stanzas XXI to XXVIII, depicting battlefield, scuffle and, since her translation includes stanzas XXV to XXVIII, she also had an opportunity to present in her translation the "Albyn ${ }^{49}$ 's hills" (hills of Albion - England), actually to remind of the bravery of the Scottish Cameron clan and its Lochiel branch which fought with distinction at the Battle of Waterloo in 1815. In her very inspired translation the reader could imagine and almost hear wartime sounds, such as "mountain-pipe" referring to the pipes, Scottish national instrument accompanied by the "fierce native daring" and imagine "dewy waves of Ardennes" with "nature's tear drops", beautiful landscape of mountainous scenery, in contrast to ugly nonsense of war. Concluding words of the citation question the sense of any war and indicating at its futility, whereas it is all the same to the victims of war - who won and who was defeated. It was generally Byron's point of view in the original too, therefore we may be well satisfied with the translation because the original voice of the author was heard in the proper manner.

Byron's poetry in the Serbo-Croatian translation was depicting his personality and views rather than some specific theme or motive. It is actually the way he was represented - by specific selections from his opus and by particular translators' choices (with regard to the common question of the translation process - what to sacrifice and what to keep). And as Abrahamayan says, all his heroes are surrogates of himself (Abrahamyan, 2013, p. 10); they are figures moving under the domination of an often obscure purpose and destiny. His work is a poetry of experience, since he broke all possible boundaries (McGann, 2008, p. VII).

Yet his personal views and his personality are not given to its fullest extent in the former Yugoslavia culture due to the fact that his satiric works remained almost unknown for the Serbo-Croatian readership. There aren't any translations of Beppo and The Vision of Judgment in the course of the twentieth century and Byron's epic poem Don Juan was translated in 1887 in prose version, and that was the only translation in the Serbo-Croatian language since then, reprinted twice - in $1957^{50}$ and $2004^{51}$. This prose translation represents great loss for Byron's original since the specific poetic form is the "carrier" of the poetic effect. Beaty argues that it was primarily the ottava rima stanza, allowing comfortable alteration of mood between sestet and couplet, that enabled Byron to sustain this dual perspective in the unresolved tension we now call "Byronic irony" (Beaty, 1985, p. 67). This blend of personal confusion and political satire, including romantic episodes and cynical comments "demonstrates Byron's wish to show that life cannot be contained within any system of thought" (Heath \& Boreham, 2000, p. 124).

\section{Lyrical Contemplations on Humanity of P. B. Shelley in the Translations Into the Serbo-Croatian Language}

The most evident trait of P. B. Shelley's poetry is his love for humanity, which is so obvious in his unshakeable belief in the future and in his optimistic view of human destiny. Beside his authentic poetic

\footnotetext{
48 Kuić, 1974.

49 "Albion is a word used in some poetic or rhetorical contexts to refer to England. It was the original Roman name for Britain. It may come from the Latin word albus, meaning 'white'. The white chalk cliffs around Dover on the south coast are the first part of England to be seen when crossing the sea from the European mainland" (James O'Driscoll, Britain, the country and its people: an introduction for learners of English, OUP, 1995, p. 10).

${ }^{50}$ Bajron, 1957.

51 Bajron, 2004.
} 
characteristics, some typical English features are also present in his poetry: love and even adoration of nature, a particular utopian view joined to reality, and a quite authentic interpretation of the Hellenic world, based on true knowledge of its literature and history. ${ }^{52}$ But to turn to the history of scholarly work on Shelley is to confront a succession of sharp disagreements, sometimes wildly divergent interpretations of his works, and sudden changes of opinion about him in short spans of time. Among his contemporaries he was often seen through his political ideas and writings, and his reputation depended on the reviewer's social or political affiliation (O'Neil, 1998, p. 118). And the post World War II reconstruction of Shelley remains wide and diverse as ever in his homeland (O'Neil, 1998, p. 119).

In the meantime, in some other parts of Europe, in the vast territory that was to become Yugoslavia, Shelley's reputation and poetic significance was established as early as the beginning of the twentieth century and has remained unchanged to this day. Not only was he seen as a poetic genius, but also as a deeply humane poet expressing the inner, innate ethos of the English people in the best possible way, i.e., through poetry. In the multi-ethnic and multi-religious Yugoslav state, in which all nations had been enslaved at some point or other in the course of their history, the aristocrat Shelley, with his feelings for ordinary workers' miseries, proclaiming liberty from any tyranny as a prerequisite for any human progress, was truly a precious voice. Such a view was created by the inspired and lyrical essays of the major Serbo-Croatian writer, scholar, translator and poet Anica Savić-Rebac. Though her earliest translations did not include any of Shelley's longer poems which contain his thoughts on revolution and his philosophical views, her knowledge of Shelley's work, apparent in her 1920 essays ("P. B. Shelley as a great poet of socialism" or "Shelley and universal lyricism") ${ }^{53}$ had a deep impact on his further destiny in Serbo-Croatian foreign literature translations. Her translations of Shelley's poetry were published at the beginning of the twentieth century (Ode to the West Wind, 1907, To a Skylark 1907, Stanzas Written in Dejection, Near Naples, 1908, The Keen Stars Were Twinkling ..., 1911, Ode to the West Wind, second version, 1920, One Word is Too Often Profaned, 1924, The Cloud, 1924, Song to the Men of England, ${ }^{54}$ 1924). ${ }^{55}$

The reputation of Shelley in Serbo-Croatian literature is best illustrated exactly by the words of Anica Savić-Rebac, the earliest lyrical translator of Shelley and renowned scholar in the former Yugoslavia, in her essay P. B. Shelley as a great poet of socialism, ${ }^{56}$ published in Serbo-Croatian in the newly-born Kingdom of Serbs, Croats and Slovenes ${ }^{57}$ in the period between the two World Wars:

Despite the fact that the need for freedom of speech is a part of the spiritual structure of the English people, the struggles for political freedom in England lasted a long time, and the process of obtaining it was slow and painful: therefore, these freedoms of the English people did not come out of a tacit agreement between reaction and liberalism, and even less did they come out as an integral part of an old political structure, but they were just the incomplete result of centuries-long struggles. What is often overlooked or deliberately ignored, is the fact that these struggles were not meant to provide some sort of luxurious and ornamental freedom, or some particular happiness akin to Goethe's idea of individual

\footnotetext{
52 "His poetry is interwoven with innumerable threads of earlier literature, of philosophy and science. His prose shows not only a great range of learning, but considerable power of argument and exposition, and his letters reveal for the most part a rather arid doctrinaire intelligence". Hough, 1963, p. 122.

53 Savić-Rebac, 1988, pp. 287-306.

54 The translation of this poem was published within the essay under the title "P. B. Šeli kao veliki pesnik socijalizma", in: Savić-Rebac, 1988, pp. 303-304.

55 All necessary data regarding publications of the listed poetry may be found in Mataric, 2010.

${ }^{56}$ Ibid 293.

${ }^{57}$ It came into existence after World War I in 1918 under the name of the Kingdom of Serbs, Croats and Slovenes by the merger of the provisional State of Slovenes, Croats and Serbs (itself formed from territories of the former Austro-Hungarian Empire) with the formerly independent Kingdom of Serbia. https://en.wikipedia.org/wiki/Yugoslavia (08/04/2017).
} 
personal development, but in the deepest sense were striving for a real improvement of life, for the biggest possible benefit of the people of England. Not only did that self-proclaimed traditional nation pass through all the disturbances caused by the peasants' revolts of the late Middle Ages, but it has also produced ideologists far more renowned than any ideologists in any other nation; and in Cromwell's civil and republican revolution, in the 17th century, there were some extremely communist ideas that even rested on a certain materialistic basis. There were the so-called Levellers, i.e., those who annul, make something flat. (...) And we can say that a single line of exposition develops from Thomas Moore, all the way to William Godwin and Robert Owen. That freedom-loving spirit of the English, in the first decade of the previous century, has produced the greatest poet of socialism in the West, the man who was the personification of the noblest inclinations of the English people, and, at the same time, one of its most powerful spirits, who was the greatest lyrical poet of his nation, and maybe the greatest in human history. ${ }^{58}$

As the twentieth century progressed, Shelley's reputation as a noble mind and soul continued to grow. In the following wave of translations, it was Ivan Goran Kovačić, Yugoslav poet, Croatian by origin, who fell at a young age in the Second World War, who was to make a great contribution to the translation of Shelley's opus. His beautiful translations of the poems "To a Skylark", "Hymn to Pan", "To-I Fear Thy Kisses Gentle Maiden", "Fragment: To Byron", "To Wordsworth", "On Keats, Who Desired that On His Tomb Should Be Inscribed-", "Night", "When the Lamp is Shattered" were published posthumously in 1947. Kovačić was among those who spoke English well and could understand Shelley's poetry in depth. As he selected poems for translation according to his personal lyrical preferences, one might assume on the basis of his selection that he was primarily enchanted by Shelley's lyricism rather than his revolutionary ideas.

The second half of the twentieth century saw numerous translations of Shelley's poetry, and to some extent the poems selected for translation immediately after World War II reveal the personal inclinations of the translators and illustrate their tendency to use Shelley for the support of the dominant national ideology of the time. Namely, Shelley's great epic Prometheus Unbound was translated in its entirety, and published in 1954 in Belgrade $^{59}$, the capital city of the newly formed Socialist Republic of Yugoslavia, devastated and ruined physically and morally discouraged in the Second World War. It is an excellent translation, which preserves Shelley's lyrical tune, melodious, rhymed, and brilliantly renders all of the poet's general motives, ideas and philosophy. The story of the liberation of man, of man's soul as a plan for human progress through love and art steeped in Greek tradition actually meant more than that for the target culture.

Whilst Western critics say that in Shelley's view man's soul is inhabited by both good and evil ${ }^{60}$, the Serbo-Croatian readership had an opportunity to see Shelley's belief that the human heart is inhabited by good only, since the Christian conviction that $\sin$ is a necessary preliminary to repentance leads, according to Shelley as self-declared atheist, to misanthropy and cruelty (Abrams, 1960, p. 257). This is because in 1954 the Yugoslav readership had at their disposal only Prometheus Unbound, where Shelley's allegory clearly points at humans as predestined for good, and exposes his humanity to an extreme level in Act I, when Prometheus cries out, repenting for the curse uttered earlier:

\footnotetext{
Prometheus:

It doth repent me; words are quick and vain;

Grief for awhile is blind, and so was mine.

I wish no living thing to suffer pain.
}

\footnotetext{
58 Savić-Rebac, 1988, pp. 294-295 (transl. Jelena Otašević).

59 Šeli, P. B. (1952) Oslobođeni Prometej, trans. Jugoslav Đorđević, Beograd: Prosveta.

${ }^{60}$ It is simply not true to say that Shelley conceives the human soul as a naturally innocent and divinely beautiful creature, interfered with by external tyrants (Abrams, 1960, p. 256).
} 
But the British readership knew Shelley's other poems well, and was familiar with lines from his Revolt of Islam in which those who come "from pouring human blood" are told

Disguise it not - we have one human heart -

All mortal thoughts confess a common home. (viii.xix)

and again,

Look on your mind - it is the book of fate -

$\mathrm{Ah}$ ! it is dark with many a blazoned name

Of misery - all are mirrors of the same. (xx.)

When Shelley looks at and condemns the oppressor, he does so with the full consciousness that he too is just a man: the evil is within as well as without (Abrams, 1960, p. 256). That is why Prometheus, without previous knowledge of Shelley's earlier longer poems, might be understood as too perfect; the appearance of so-called Necessity, or "natural order" might not be understood properly, because it is an idea that Shelley elaborately developed in his earlier works before finally incorporating it in this masterpiece - Prometheus Unbound. Necessity was to Shelley both a philosophical and a psychological concept: in Queen Mab necessity denotes a cosmic power, whose rule is absolute both in the material and in the moral world, but a power which will inevitably produce social, institutional and even climatic changes (Baker, 1948, p. 5). In Alastor it is another kind of necessity which stands at the centre of the poem: "the imperious psychological necessity of love, which is represented by the visionary maiden, Shelley's first nympholeptic myth" (Baker, 1948, p. 6). And The Revolt of Islam reexamines "the necessitarian law of Queen Mab", to conclude that "good and evil are inextricably mingled in the organization of the cosmos, and that Necessity is an amoral force on which man cannot afford to depend" (Baker, 1948, p. 6).

The Serbo-Croatian readership received Prometheus Unbound translated without previous knowledge of Shelley's earlier epics, i.e., longer poems in which he gradually developed his views on revolutionary ideas. For Shelley, tyranny and oppression harden the hearts of those that suffer, but this hardness should not prevail when revolution comes in order to obtain freedom, because, like the quote from Prometheus states, "grief is blind"; and this grief should not be the root of the liberation revolution because it brings no good, and revolution fighting for freedom should have only good motives; believing in the goodness of the human heart, rejecting any idea of revenge, particularly if it involves the brutal use of force. This is poetically expressed in The Revolt of Islam when Laon, in an already very familiar plot, prevents violence against the dethroned tyrant king, or when he, in The Masque of Anarchy, in the second part, recommends passive resistance to the gathered people of England in the event of an attack by the tyrant:

'With folded arms and steady eyes,

And little fear, and less surprise,

Look upon them as they slay

Till their rage has died away.'

'Then they will return with shame

To the place from which they came,

And the blood thus shed will speak

In hot blushes on their cheek. ${ }^{61}$

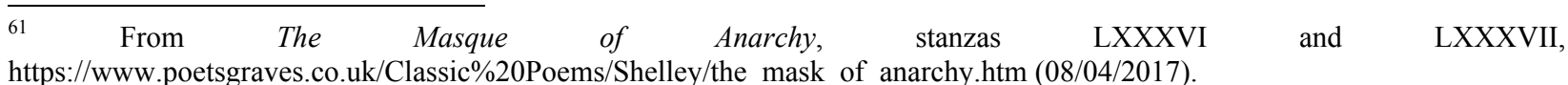


The origin of evil, which undoubtedly exists, Shelley cursorily expressed at the beginning of his poetic career, never fully defining it. Its origin and status Shelley never succeeds in defining, or even in symbolizing adequately. It is not nature, it is kings, priests and statesmen who "blast the human flower even in its tenderest bud"; and this "unnatural line of drones springs from vice, black loathsome vice" (Hough, 1963, p. 125). Since Prometheus Unbound rounded off this series of so-called revolutionary epics like Queen Mab, The Revolt of Islam, The Masque of Anarchy, and was published after this series of longer poems, one can surmise that the readership of the former Yugoslavia saw a very incomplete image, due to the fact that neither of these epics was translated in Serbo-Croatian in the twentieth century. And as yet there are no translations of them.

Thanks to the efforts of the famous Serbo-Croatian translator and renowned scholar Ranka Kuić, a short insight into Shelley's longer poems was provided during the 1960s and 1970s. Only parts that could be read separately and independently of the whole were translated - parts clearly glorifying freedom, equality and fraternity among people, which were completely in line with the dominant communist ideology of the former Yugoslavia at that time. The selection of lines for translation is quite suggestive in the sense that it was as if the translator wanted to make a compilation of excerpts in such way as to present Shelley's revolutionary ideas as universal and timeless, and not meant for any particular country or historical moment. We know today that Shelley's major incentive was his disappointment with the outcome of the 1789 French Revolution and its consequences. It was not possible to gain a deeper insight into Shelley's ideology from the short excerpts from his longer poems that were translated and published in 1964. The same book of translations of his poems was reprinted later in 1969. The collection of Shelley's poems translated by Ranka Kuić is organized in several chapters with titles suggesting the themes and motives of the poems selected: On Nature, On Love, To Revolution and Liberty. She also offered at the end of her book ${ }^{62}$ a short description of all the poems included, as well as a summary and an overview of his longer poems.

Some of Shelley's poems were translated into Serbo-Croatian several times during the twentieth century: Indian Serenade (1903, 1914, 1964), To the West Wind (1907, 1920, 1923, 1956, 1958, 1979, 2000), To a Skylark (1907, 1947, 1964, 2000), Stanzas Written in Dejection near Naples (1908, 1964), One Word is Too Often Profaned (1924, 1964), The Cloud (1924, 1951, 1956, 2000), Love's Philosophy (1932, 1966, 2009), Good Night (1925, 1964), To the Moon (1942, 1964, 2009), I Fear Thy Kisses (1947, 1964), To Wordsworth (1947, 1964), To Night (1947, 1964), When the Lamp is Shattered (1947, 1964, 2009), To William Shelley (1964, 2009), To Mary Shelley (1964, 2009), From “Adonis” (1964, 2009), A Widow Bird Sate Mourning for her Love $(1964,2009)$.

Later translations into Serbo-Croatian, those that were published by the end of the twentieth century and later in the first decade of the twenty-first, reveal the same interest of translators in Shelley's shorter poems, thus leaving his lengthy ones for some other generation to translate. Regretfully, an overall image of Shelley's poetic genius seems incomplete in translation due to the fact that in the songs that were popular and were translated, one can only see the author's personal and emotional motives and the revolutionary ideas and the full development of a rounded ideology with a complete psychology of the human mind, symbolically investigated in Prometheus Unbound. Therefore, one cannot but regret for the situation regarding translations into Serbo-Croatian language and entice, at least, through this paper, the translation of the entire Shelley's opus.

62 Šeli, Persi Biš (1969) Pesme, Beograd: Rad. 
What one cannot really grasp from the poems selected for translation is all the complexity of the poet's personality - his lyrical sensitivity and revolutionary ideal - which are best expressed in the poem Alastor, Or The Spirit of Solitude. In the preface to the poem, Shelley, interpreting the poem's main idea, says that his character - the poet himself, in a completely egoistical manner, longs for a meeting with some "intelligence similar to himself", with a being almost perfect, marvelous - superior. While looking for that superior being, Shelley sees proper narcissism, an opinion of himself as a superior being and because of it - aware of that "egotism" as he himself used to call that feature - condemns his character, nameless, to death. That "egotism", longing for solitude and escape, self-love, is the complete opposite of his political and philosophical views that can be found in his 1813-1819 longer poems (Queen Mab; The Revolt of Islam; The Masque of Anarchy; England in 1819; Sonnet to the Men of England) in which we can trace the idealistic component of his work his rational attitude, that was not in full accord with his emotional being. It is exactly in that discrepancy that Shelley's poetic talent and lyricism come out, and these psychological boundaries are barely visible. That is why the absence of Shelley's longer poems in translation is an obstacle to fully comprehending his poetic mind and work.

If we classify Shelley's poetic works according to style and form into longer narrative poems, verse plays and shorter poetry, we have to notice the absence of the longer poems that express his poetic mind and revolutionary thought, which further emphasize Shelley's talent and his sensitivity. Those longer poems were presented to the Serbo-Croatian readership only through certain excerpts that seemed apposite for the target culture's needs to support the idea of liberty and revolution for a just cause, as well as the idea of equality in a communist society such as the one that was established in the former Yugoslavia at the time when these translations appeared. This generalization through meticulous and elaborate selection of excerpts specifically glorifying equality and liberty is best visible in the work of Ranka Kuić, who played a significant part in bringing Shelley to a wider audience in the former Yugoslavia.

\section{Conclusion}

The major English Romantic poets, Wordsworth, Coleridge, Byron and Shelley, or their works translated into Serbo-Croatian greatly contributed to the literature of the target culture. Beside, the translations also gave those poets an afterlife in another culture, in another century. Their poems were translated almost one hundred years after their first appearance among the English-speaking readership, except for Lord Byron's poems, which inevitably reached western Balkan countries earlier due to his considerable reputation all over Europe. The former Yugoslavia, where in the twentieth century the official language was Serbo-Croatian, and which was composed of nationalities that for centuries had been under foreign rule, finally found a national identity and the freedom to use a national language; in order to enrich its own literature, the country found it very useful to involve foreign writers and extend the field of its own literature across borders. What this expansion brought was not only a broadening of knowledge about the British poets of the Romantic era but of the English people as a whole through their best ambassadors - poets.

Translators played a crucial role in the process of introducing the English nation and English culture through their romantic poems. Their involvement resulted in the establishment of not just literary, but also cultural ties between two nations. The analysis of the translated poems, and also the poems selected for translation, reveals the central role of translators. 
Through translations of Wordsworth's poems, the Yugoslav reader in the twentieth century could see the beauty of the English landscape, hear its rivers, imagine London in the dusk and in harmony with nature, being its inseparable urban part.

Through the excellent and inspired translations of the best Serbo-Croatian scholars and translators, Coleridge's visions and fantasy too were revealed, - abundant, rich and unattainable, depicting some fantastic world opening up for a discourse with eternity through the power of the human mind, showing the enormous potential of literature and poetry in the service of the poet's nobler goals and, at the same time, of humanity. The Yugoslav readership was impressed by miraculous visions, and also had the opportunity to integrate English cultural identity enriched through a turbulent and dynamic history.

Lord Byron was seen as an English aristocrat who, despite his origin, felt strong sympathy for enslaved peoples, despised the hypocrisy of his own social class and loved his homeland.

And finally Shelley, also an English aristocrat, atheist and rebel, through translations into Serbo-Croatian was represented as a deeply sensitive personality opposed to any kind of tyranny, proposing liberty, equality and fraternity, envisioning human progress through art and love.

\section{References}

Abrahamyan, S. (2013). Byron's satire as a means for social change. Proceedings of The International Association of Byron's Societies, London.

Abrams, M. H. (1960). English romantic poets, modern essays in criticism. Oxford University Press.

Bajron, D. G. (1965). Hodočasce Čajlda Harolda (Pilgrimage of Childe Harold). trans. Danko Anđelinović. Zagreb: Matica Hrvatska.

Bajron, D. G. (1996). Čajld Harold (Childe Harold). trans. Luko Paljetak. Zagreb: Školska knjiga.

Bajron, D. G. (2004). Čajld Harold (Childe Harold). trans. Nataša Tučev. Beograd: Zavod za udžbenike i nastavna sredstva.

Bajron, L. (1957). Don Žuan (Don Juan). trans. Okica Gluščević. Beograd: Narodna knjiga.

Bajron, L. (2004). Don Žuan (Don Juan). trans. Okica Gluščević. Beograd: Politika, Narodna knjiga.

Baker, K. (1948). Shelley's major poetry: The fabric of vision. Oxford University Press.

Beaty, F. L. (1985). Byron the Satirist. Illinois: Northern Illinois University Press.

Đukić, T. (1966). Poezija vekova (Poetry of centuries). Beograd: Kultura.

Đurić, V. (1965). Lirika (Lyrics). Beograd: Zavod za izdavanje udzbenika i nastavna sredstva SRS.

Evans, I. (1970). A short history of English literature. Harmondsworth: Penguin Books.

Heath, D., \& Boreham, J. (2000). Introducing romanticism. Cambridge: Totem Books.

Hough, G. (1963). The romantic poets. London: Hutchinson's University Library.

Jackson Bate, W. (1987). Coleridge. Harvard University Press.

Jagličić, V. (2009). Danse Macabre, Antologija anglojezičkog pesništva od XIV do XX veka (Danse Macabre, an anthology of the poetry in English from XIV to XX century). Kragujevac: Univerzitet u Kragujevcu: Studentski kulturni centar.

Kićović-Pejaković, S. (1973). Engleska književnost u Srba u XVIII i XIX veku (English Literature in Serbia from XVII to XIX century). Beograd: Institut za književnost i umetnost.

Kolridž, S. T. (1969). Pesme (Poems). trans. Ranka Kuić. Beograd: Rad.

Kovačić, I. G. (1947). Prijevodi strane lirike (Translations of foreign lyrics). Zagreb: Nakladni zavod Hrvatske.

Krklec, J. (1956). Antologija svjetske lirike (An anthology of world's lyrics). Zagreb: Kultura.

Kuić, R. (1989). Antologija engleske romanticarske poezije (An anthology of the English Romantic poetry). Beograd: Naucna knjiga.

Matarić-Radovanov, M. (2010). Engleska književnost kod Srba 1900-1945 kroz časopise (English literature in Serbia 1900-1945 in magazines). Pančevo: Mali Nemo, Beograd: Itaka.

Mc Gann, J. J. (2008). Introduction // Byron, Lord. Selected poetry. Oxford University Press.

O’Neil, M. (1998). Literature of the romantic period: A Bibliographical guide. Oxford: Claredon Press. 
Paljetak, L. (1996). Antologija pjesništva engleskog romantizma (An anthology of the English Romantic poetry). Zagreb: Konzor. Pavić, M. (1968). Izabrana dela: dramske poeme-spevovi-pesme (Selected works: Verse dramas-narrative peoms-songs). Beograd: Prosveta.

Pavlović, M. (1978). Pesništvo evropskog romantizma (Poetry of the European Romanticism). Beograd: Prosveta.

Petrović, I. M. (1989). Lord Bajron kod Jugoslovena (Lord Byron in Yugoslavia). Beograd: Institut za književnost i umjetnost.

Purešić, D. (2010). Blejk-Berns-Vordsvort-Bajron-Šeli-Kits, Poezija engleskog romantizma (Blake-Berns-Wordsworth-Byron-Shelley-Keats, Poetry of the English Romanticism). Beograd: Plato.

Purvis, J. (1990). A preface to wordsworth. London: Longman.

Rogers, P. (2001). The Oxford illustrated history of English literature. Oxford University Press.

Sanders, A. (2004). The short Oxford history of English literature. Oxford University Press.

Savić-Rebac, A. (1988). Studije i ogledi (Studies and examples). I-II, Darinka Zličić (ed.), Novi Sad: Književna zajednica Novog Sada.

Šeli, P. B. (1952). Oslobođeni Prometej (Prometheus Unbound). Beograd: Prosveta, 1952. prev. Jugoslav Đorđević.

Šeli, P. B. (1969). Pesme (Poems). Beograd: Izdavačko preduzeće Rad.

Žigić, D. (1967). Prevodi poezije engleskih romantičara kod Srba i Hrvata od Prvog svjetskog rata do danas (Translations of poetry of the English Romantic poets in Serbia and Croatia from the First World War until today). Beograd: n. p. 